Весна Половина

Универзитет у Београду

Филолошки факултет $81^{\prime} 42$

https://doi.org/10.18485/ai_lik.2018.4.6.6 оригинални научни рад

\title{
ЈЕЗИЧКА НАРАТИВНА И АРГУМЕНТАТИВНА ОБЕЛЕЖЈА У ТЕКСТУ „ЈАЗАВАЦ ПРЕД СУДОМ“ П. КОЧИЋА
}

Обележја наративног и аргументативног често су испреплетана у различитим текстовима па и у овом: „Јазавац пред судом“ Петра Кочића. У анализи овог дела Петра Кочића уочава се специфичан распоред наративних и аргументативних сегмената, а посебну пажњу посвећујемо исказима које сматрамо обележјима наративног и аргументативног типа.

Кључне речи: наративна обележја, аргументативна обележја, лингвистика текста.

Увод. У лингвистици текста се одавно поставља питање типова текста. Иако се могу нашироко наводити расправе о разврставањима и критеријумима за различита класификовања, за потребе овог рада указаћемо само укратко

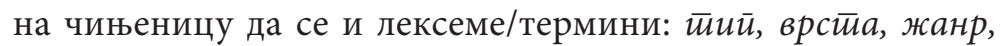
и слични њима, врло често употребљавају синонимно, те се нпр. говори о наративном жанру или наративном типу или врсти текста или дискурса, итд. Примера ради, врсте текста могу бити и: уредба, закони, рецепти, упути, извештаји, новински текстови, постови на фејсбуку, честитка, и могло би се дуго још набрајати. Такве су врсте историјске категорије, културно обележене, имају своје прототипичне форме (Костић-Томовић 2016), и као што је имплицирано овим списком, углавном се односе на целину текста. Стога би их други лако могли назвати некњижевним жанровима, за разлику од књижевних жанрова: драме, епике, романа,

* polovinav@fil.bg.ac.rs 
приповетке и сл. Све ове „врсте“ текста имају своја типична обележја, рекосмо, али је исто тако чињеница да ретко можемо наћи примере који су искључиво, и доследно, по свим својим обележјима само један тип или врста текста.

У анализи „Јазавца пред судом“ Петра Кочића као основу нашег приступа под типовима текста подразумевамо: наратив, опис, и аргументативни текст. Они су минимално дефинисани према томе да ли се ради о „стањима“ (опис), „промени стања“ (наратив) или о „логичко-семантичким односима“ (аргументативни текст) (Caranzza 2015). Семантичка и текстуална језичка анализа тиме бивају релативно ограничене, али допуштају да се на сегменте текста, односно мање или веће скупове реченица гледа из перспективе наративности односно аргументативности, а из перспективе лингвистике текста утврде неке позиције, дистрибуција и комбиновање ових типова текста унутар целине дела.

Док је релативно лако утврдити дескриптивне и наративне сегменте текста, аргументативни сегменти у неком чистом виду ретко се могу наћи, јер се и сви остали типови текстова, опис, нарација, или рецимо објашњења, илустрације и сл. могу наћи као делови аргументације. Штавише, често су критеријуми сврхе или улоге неког текста или дискурса примарни у оцењивању да ли је он аргуменатативан или не (Fludernik 2009). У сваком случају, типична је употреба аргументативних текстова у ситуацијама као што су судски процеси, а управо је та ситуација тема Кочићевог дела. Претпоставља се да свака од страна има одређено стајалиште, позицију коју жели доказати другим ставовима, за или против онога који има супротна страна. У Кочићевом „Јазавцу пред судом“ два стајалишта доминирају: „Јазавац је учинио криво и треба га казнити“, и ово стајалиште бива прихваћено од стране суца, и „Свет (царевина) како га види Давид није исти каквог га виде цареви чиновници“, стајалиште које, чини се, Давид и не очекује да они прихвате, али ипак има потребу да изнесе све доказе који га потврђују. 
Наш циљ у овом раду је да анализирамо како језичким путем писац распоређује и комбинује ове типове текста стварајући кохерентно дело.

Дескриптивни и наративни искази на почетку и крају целине. Дело Петра Кочића „Јазавац пред судом“, у целини, отпочиње уласком главног јунака Давида Штрбца у судницу и завршава се његовим изласком. Две су ствари интересантне у погледу типа текста и језика: 1. У почетној дидаскалији налазимо „опис“ главног јунака, прво без глагола: мален, низак, сув као їрана, лаїан као иеерие. Затим са глаголима у презенту којим се означавају сталне особине јунака: Лијева му је ноіа мало краћа оg gесне, йе се їеїа каg ияе. Очи му се свијетле и иррелијевају као у мачке из мрака... да би, пред крај ове прве дидаскалије, следиле две реченице са правим презентом: Улазећи у суgнииу, крстии се и gржи јазавца свезана у врећи. У јазавца вири само ғушка uз вреће. Насупрот томе последња дидаскалија у драми је далеко краћа, и садржи опис промене изгледа Давидова, са

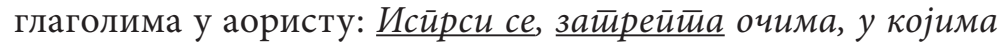
се засвијеитлише сузе неизмјерне мржне и йакосиии. 2. Док на почетку драмског дијалога прве реплике Давидове садрже само поздраве на које судац и писар не обраћају пажњу, те се он обраћа свом јазавцу, и тиме је његов низак социјални статус као мале и неважне особе утврђен, у последњој реплици којом се закључује драма Давид каже: у мени има милијун сриа и милијун језика, јер сам данас ирреg овим суgом йлако исйреg милијуна gуша које су се оg силног gобра и милине умриивиле йа јеgва gишу! Тако, употребљени аорист у последњој дидаскалији и перфекат у наведеној реченици на самом крају целог дела представљају „промену стања“ и тиме потенцирају идеју да је Давид дошао да „исприча“ све муке које тиште народ, те је, иако драмски, дијалошки текст у питању, или „еглен“ како каже Давид, његово било све по реду да каже шта мисли о царевини.

Сегменти и целина. Цео текст би се могао условно поделити на неких петнаестак краћих или дужих сегмената: Упознавање и представљање Давида суцу, Најава тужбе против јазавца, Образложење Давидово да он (а и његова 
жена) познаје царске законе, Најава излагања тужбе уз пуштање јазавца из вреће, Казивање о царској „правди“, О страху од жене и о жени, О газдама, О писарчићевом имену, О јазавчевим „генералијама“, Пресуда јазавцу, Позив доктору, Докторов „преглед“ Давидове главе, Окончање дијалога. Језичка обележја и функционалност појединих сегмената се доста разликују, иако би се могло свима приписати истицање Давидовог лукавог вођења дијалога и исмевање царских службеника. Тако, на пример, један део: о жени (и женидби Давидовој) представља типичан пример хумора базираног на вишесмислености, лексичкој и синтаксичкој, датог лексичког поља: оженитии се уgовицом, женитии жену, gјевојком оженитии и сл. Овај део може имати само улогу приказивања Давидове вештине да збуни саговорника, али не доприноси битно ни основној причи нити аргументацији о страдањима српског народа. Навешћемо само две реплике да то илуструјемо:

ПИСАРЧИЋ: Па добро, кад је тако млада, онда си је мора дјевојком оженити.

ДАВИД: (уйрейасииио се og чyga): Ама, шта је теби?! Како ћу ја жену дјевојком оженити? Шта би то онда било? Бога ми, дијете, ја би реко да ти нијеси саставио око лијеске... Што ћу ја жени дјевојку доводити!...

Очигледна је игра речима. Синтагма gјевојком оженийи може се синтаксички тумачити на два начина: „оженити се дјевојком“ и „оженити њу дјевојком“, али културолошки ово друго тумачење је неразумно, те управо том чудном интерпретацијом Давид и исмева саговорника.

Наративни сегменти и аргументативни тип текста. Многи су у лингвистици текста тврдили да се наративом могу сматрати и веома кратки текстови од по једне, две реченице. Практично би онда и следећа реченица из текста: Тужим іа славном суgу јер ми је изио читиаву юиву куруза, са глаголом у прошлом времену могла бити проглашена наративом, или бар најавом наративног текста. Ипак се у већини анализа наратива очекује и одговарајућа структура, 
какву, на пример даје Лабов (1967): апстракт, оријентација, компликација, евалуација, резолуција и кода (наравно, ово није једина могућа и постојећа класификација структуре наратива, али то тренутно није предмет овог рада). У том смислу, наративни тип текста налазимо на више места у тексту овог дела, и њихова функција је изразито аргументативна. Навешћемо пример једне краће нарације:

Нећу йреко закона, йа уби ме!... Неке іодине, gок још нисам био свјешитио вашеі закона, убио сам у йој истиој

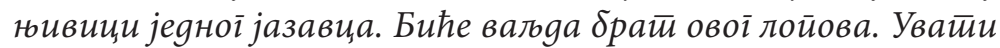

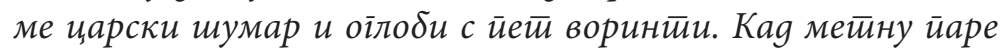
у иети, оштиро ми заиријетии: „Не смијеш йо више чинитии, јер и јазавца gанашюи закон брани“"Е, каg іа брани, нек му и суgи каg шиметеиу йочини!...

Иако нису сви горе наведени структурни сегменти присутни у овом наративу (а и иначе није нужно да сваки наратив има све сегменте), ипак је већина присутна: оријентација, којом се уводи актери, време и физичко окружење „Неке іолине... у йој истиој ғивици јеgноі јазавиа“, компликација - Уватии ме изарски шумар и оіллоби с иеети воринити..., резолуција која показује како се разрешио проблем - Kag метину йаре у ией, оштиро ми заиријеиии: „Не смијеш йо више чинитии, јер и јазавиа яанашғи закон брани.", као и евалуа-

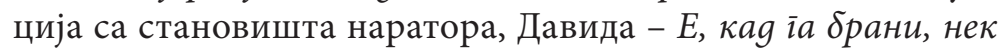
му и суgu кag шиметиу йочини. Тиме је експлицитно исказана и аргументативна позиција овог наратива: „Ако закон брани јазавца, онда закон може и да казни истог“. Можемо рећи да ово стајалиште у аргументацији, које би се простом заменом лексеме „јазавац“ неком уопштенијом речју, нпр. некоїа, могло уобличити у исказ о апстрактном логичко-семантичком односу, типичном за аргументативни тип текста.

Други уочљив тип наратива у Кочићевом делу, јесу наративи у коме доминирају препричавања, односно цитирања дијалога међу актерима. Такви су наративни текстови о разговору са женом и припреми за долазак у суд, расправама са газдама Србима, где се прошлим глаголским временом и адвербијалима даје оријантација на почетку, а на 
крају евалуира: ga $\overline{\boldsymbol{u} и ~ с е ~ к о ј о м ~ с р е ћ о м, ~ ј у т и р о с ~ \delta и л о ~ о к л е н ~}$ иррикрасиии... зайаюио се ја оg чуgа, или Поче ме жена јеgном йући.... и ја се сйасо; Неки ме ван, баш ће битии у йрошли

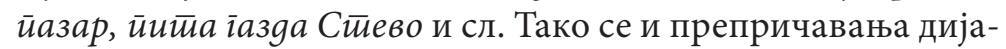
лога из неких сусрета уобличавају у наративни догађај.

Ипак, најдужи монолог и најдужа реплика у драми садржи причу, или боље рећи четири кратке приче које илуструју како је „славни суд ослободио“ Давида од четири „напасти“ - сина, краве, коза, и прасца:

ДАВИД: Да, да, од млоге ме је биједе и напасти ослободио. Све ћу вам, господини моји, казати по реду и закону. Имо сам сина. Снажно, младо и витко момче ко јела. Није био нимало на ме налик. Бацио се био на ђеда, мога оца, што je у пошљедњој буни у Црним Потоцима погино. Снажно и витко момче, али наопако и злочесто да бог милостиви сачува! Узеше га у војску, послаше га у Грац и ја дану душом. Лани, око Часни верига, донесе ми кнез црну књигу и $\bar{m} р и$ воринта: „Давиде, умро ти син, па ти царство шаље три воринта. То ти је награда.“ „О, добре царевине, крст јој љубим!“лијейојајаукнуодраяосиии, аженаи ијеиазайлакаще. „Брате, кнеже, врати ти та три воринта царевини. Право ће бити и богу и људима да то царевина узме себи ко, рећемо каз'ти, неку награду, јер она је мене од напасти ослободила.“ - Онда сам имо једну краву, добру, дебелу краву. Од уста сам своји откидо па сам њој даво. Кажем вам, добра, дебела крава, али зијанћараста, да бог заклони! Прескочити преко плота и ограде куд занесе! Сатра ми сваке године љетину. Дочу то некако славни суд. Ето ти једног дана оног шикуције што купи мирију и порез: „Давиде, вели, дочуо суд да те снашла биједа, па ме је посло да... Како би било да ми ту несретну краву претеслимимо царевини, па нек се она тамо ш њом мучи и девера?“” „вала, велим ја, иаревини која се йолико за ме брине! Води, брате, води одма!“ - Онда сам имо четри козе. За турског суда мирне ко овчице, а кад заступи укопација, ошјетише и оне слободу, бог и' убио, па се не дају сносити! Почне и' она моја крезуба бабетина мусти, а пошљедња ногом у кабо, па пролије варенику. Дочу јопе некако царевина. Ето ти шикуције: „Помози бог, Давиде! Здраво, мирно?“”Добро, вала богу, како си ти?“ Туј се упитасмо за здравље, док шикуција поче: „Тебе, Давиде, 
зар јопе снашла напаст: немирне ти козе, па пролијевају варенику? Како би било да и’ предамо порезном уреду, па нек се он ш њима мучи?“ „О, да добре царевине, милостиви боже!“ занесо се ја и тијейо јаукну' о н некакве силне милине, а жена и gјеиа оg велике раяосӣи зајецаше. „Гони, брате, љубим ти стопе твоје, гони!“ И, богами, чојек - вала му, вала и њему и премилостивој царевини! - оћера несретнице и опрости ме напасти. - Од свега мала и имаћа остаде ми још један прасац, добар, дебо прасац, али зијанћараст и несрећа једна! Потра курузе, поједе тикве и мисираче, све поједе и пождера, да опростите, ко какав шикуција. Направим му јармац и метнем вако ко сад теби (склайа руке и йоказује на Писарчићу), не буди примијењено, око врата, али не помаже. Скочио свијет на ме ко на бијелу врану: „Твој прасац, Давиде, упропасти и тебе и нас!“ Од уста до уста, док и царевина не дочу. Ето ти шикуције: „Е, баш си, вели, Давиде, баксус! Ни у чем ти се не да!“ „Доста, брате! Знам!“ викну ја, па га загрли и пољуби. „Доста! Гони! Вала йи, вала и тиеби и ирремилостиивој иаревини која се она за ме йолико брине? Вала вам ђе чули и не чули!“

Као што се види, структурни наративни сегмент апстракт је дат уопштено, уз то је још и најављена нарација „йо реgу и закону“. Прве три нарације почињу сличном оријентацијом. - Имо сам сина. Онда сам имо јеgну краву. Онда сам имо чейри козе. Следе обавезно позитивне особине тих „јунака“, да би непосредно пред наративну компликацију за сваког од њих истакао да су: наойако и зло-

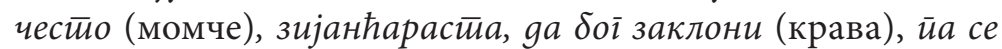
не gajy сносити (козе). И то је „компликација“ коју „разрешава“ увек чиновник државни, славног суда, и то тако што син гине, а краву и козе му одузимају, уз смешно мало накнаду. Једино се последња од ове четири нарације разликује. Најдужа је компликација као део наратива, једино ту Давид покушава сам да разреши ситуацију, чак се и „свијет“ буни због његовог прасца. И ту се једино евалуација као наративни сегмент јавља већ као део разрешења, те чиновник ни не мора да каже да му одузима прасца већ сам

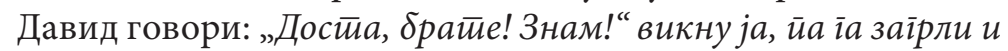

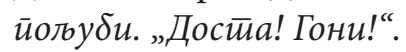


Мора се ипак истаћи да су евалуативне реченице, које смо подвукли у овом тексту посебно значајне за целину Кочићевог дела, којима се такође и завршава свака прича, иронично захваљивање царевини на неделима, а поготово хиперболичне и саркастичне реченице: тијейо ја јаукну og раяостии, а жена и дјеца зайлакаше; тијейо јаукну' оg некакве силне милине, а жена и gјеиа оg велике раяости зајецаше. Управо ти језички склопови - плакања од силне „доброте“ царевине провлаче се кроз цео текст, углавном у вези са „добрим“ које је искусио Давид, да би на крају текста уопштио и казао да је „плакао за милион душа које су се од добра умртвиле“.

Овај наратив, не само да је истакнут по својој дужини и ритмичкој структури, по семантичком контрасту и сарказму, већ представља и снажан доказ који појединачном животном причом Давидовом доказује став да је уопште „Свет царевине каквог га види Давид“ сасвим супротан од онога како га виде судац и писарчић.

\section{Аргументативна ситуација и односи моћи.}

Обраћања. Иако у формалној ситуацији какво је суђење и комуникација у суду један саговорник, судац, увек управља комуникацијом, има права и дужност да даје и одузима реч тужитељу и другим учесницима, па и да инсистира шта ће се рећи и како, итд., у Кочићевом тексту постоје варијације на пример, у обраћању: од іосйоgини до

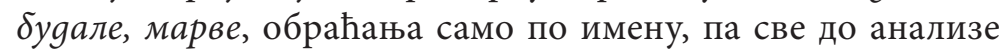
имена (...йођеш ти доље кроз Лијевче, исйоg Баюе Луке, сваком је іотиово gруїом чојеку име Тетиоје или Неgо. Пођеш ли іоре Гламочу, йа срейнеш чојека, вичи: „Помози бой, Сава!“

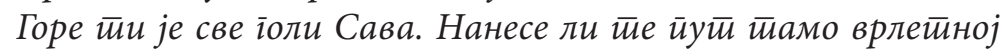
и каменитиој Лици, скияај кайу и вичи: „Добар дан, Дане!“ или „Добар gан, Мане!“). Обраћа се често и Давид самом себи и јазавцу, па и другима у дијалозима које препричава, али је са становишта аргументационог типа текста, посебно важно истаћи однос његов и суца. Тако је уочљиво да се Давид најчешће обраћа са іосйоguне (и варијацијама: 
велевлажни, славни, ілаватии...) суцу (52 пута), а овај њему са Давиge (51 пут), док је млади писар назван и guјeйе и вузле вузласйо и сл.

Међутим са становишта аргументативног текста још је интересантнија употреба лексема којима се не обраћају директно Давиду ни судац ни писар осим изнимно, али

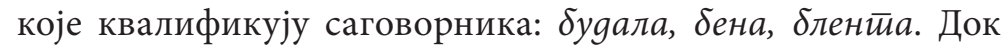
је примереније такву реч чути у неформалним ситуацијама (попут разговора са женом, која га подучава како се понашати и шта рећи у суду, па му каже: Hajūpuje ajge gоље y 'нај наш мали, сељьчки суg, буgало јеgна буgаласйа!), такве речи нису примерене судници.

Дакле, ређи су моменти када се ове лексеме користе директно, кроз вокативни облик, и то углавном на почетку драме, када се судац тек упознаје са Давидом. Након необичног обраћања Давиду, у ситуацији када их Давид више пута ословљава и пита за здравље фамилије, а то није уобичајено у суду, судац га први пут ословљава са $\delta y g a \pi o:$

СУДАЦ: Ама, шта је теби, будало? Оклен си? Како се зовеш?

Много се чешће дешава да приписују особину „будале“ Давиду кроз реченице типа: „Ти си будала“ или „Он/ово

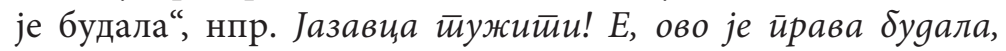

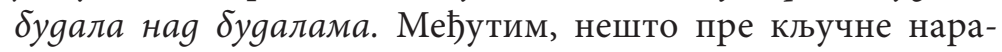
ције, отприлике у четвртом делу драме, наилазимо на промену у ставу суца. Навешћемо одломак значајан за нашу анализу (Давид је уз дозволу суца пустио јазавца из вреће):

\section{ПИСАРЧИ}

будала и ниси будала.

Пример са употребом речи маїарче уводи нас у понављање као средство контрирања. У прве две наведене реплике понавља се реч маїарче. Зарез у Давидовој реплици испред маїарче може бити синтаксички двосмислена - вокатив се одваја зарезом, али и пауза испред цитата се може тако одвојити. Да то није случајно показују и две 
друге сцене касније где се сличан поступак експлицитније приказује. Једна је:

СУДАЦ: Шути, марво једна!

ДАВИД: Шути, марво једна! То је лако рећи. Ето и ја велим.

А још јаснији је следећи пример, у коме сучева последња реплика показује да је схватио да Давидово понављање тих исказа има и потенцијално исто увредљиво и потцењујуће значење:

СУДАЦ: Ти си, Штрбац, права правцата будала. Јазавца осуђивати! Ти си луд, божји човјече!

ДАВИД (Као увријеђен, љуииитио): Немој ти, господине, тако! Док јадни тежак свјешти ваш ред и закон, а ви одма: ти си луд, ти си будала...

СУДАЦ: Ти то, Давиде, показујеш руком на ме: Пази-де се!...

У другом делу горе наведеног одломка, након Давидовог подсећања да је пуштање јазавца одобрио судац, овај по први пут закључује да Давид и није можда будала. И овај став се до краја понавља, на пример у сегменту текста који је тематски везан за погађање имена писара:

ПИСАРЧИЋ: Ја би река, господин судац, да је он бена?

ДАВИД: (їлеga ì йрезриво): А ја би јопе река да он није бена! Како ти, болан, мореш рећи да сам ја бена? Ја за тебе нијесам никад чуо нити сам те до данас својим очима видио, па јопе знам како ти је име. Оћеш да се окладимо; о главу да се окладимо?

Након Давидовог излагања о типичним именима, и наравно, након што је погодио име писарчића, судац закључује, и то супротно ономе што је до тада говорио, и супротно начину на који се до тада обраћао Давиду:

СУДАЦ: Па ти, Давиде, ниси, како видим, будала?

ДАВИД: Ко каже да сам будала?

СУДАЦ: Не каже нико, него... Како ти можеш, божји човјече, тужити јазавца?

Да би пред сам крај драме, рекао доктору који ће прегледати Давидову главу: 
СУДАЦ: То је тај сељак што тужи јазавца. Молим Вас, господине докторе, да га прегледате. Сад ми се чини будала над будалама, сад опет врло бистар и паметан. Чудновато и загонетно створење!

Иако ови искази не доприносе аргументативном дискурсу на начин на који то чине наративни сегменти текста, они ипак јасно указују на промену односа моћи која се мења и увећава како одмиче драма. Док је судац на почетку јасно и без ограда казивао да је Давид будала, луд и сл., касније све више ублажава и модификује такве квалификације модалним исказима: Како вияим, чини ми се.

Управљање разговором. Са становишта моћи, давање и одузимање речи, право да прекида саговорника у судници се сигурно може приписати суцу. Ипак, чини се да је управо у том аспекту Давид способан да преузме контролу. Тако опомиње суца за начин на који говори: Ама, йо није у најмағу руку у реgу gа рече јеgан, рећемо каз'ти и, иарски службеник, писарчића неколико пута опомиње да га не пре-

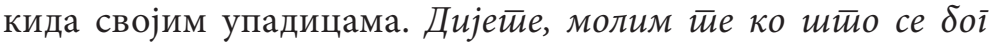
и сйарији моле, не ӣрекияај ме у ријечи! Не ӣрекияај ме у

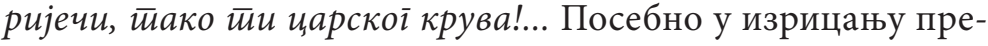
суде јазавцу, Давид после сваке реченице суца прекида га и сам говори. Нпр.

СУДАЦ: (устйage): Давиде, чуј сад! Закон осуђује...

ДАВИД: А камо оно: У Име Његово? А, не, господине! То ништа не припознајем! ... (Следи подужи пасус у коме инсистира на исправном изрицању пресуде)

И не само то, више пута унутар својих реплика, Давид се са доказивања својих уверења везаних за недела царевине према народу, враћа на суђење јазавцу, на „конкретну“ ствар, на пример:

Зар да се ја дигнем у буну? Болан, болан, ја би главу своју положио за 'вај суд!... Него, преклињем те, главати господине, да овог лопова што теже осудиш. 
На тај начин главни јунак показује своју надмоћ и у судници, мада, као што смо већ напоменули, резултат његове аргументације у вези са два стајалишта, првим у односу на јазавца кривца бива успешан, док важније, друго стајалиште остаје, бар у односу на саговорнике, суца и писарчића, ипак само исказано, што судећи и по последњој реплици у драми, и беше основни циљ Давидов.

Закључак. Као основа за ову анализу издвојена су два стајалишта као елемената аргументативног типа текста, и утврђено је да неки наративи у оквиру целог текста битније доприносе подржавању тих ставова него други наративи, али и да је њихова дистрибуција значајна. Осим тога, битна је и лексика и структурирање разговорних корака који указују не само на међусобне односе међу ликовима драме, односе моћи и потчињености, већ и на динамику развоја аргументативног дискурса.

\section{ИЗВОРИ И ЛИТЕРАТУРА}

Carranza, I.E. „Narrating and Arguing: From Plausibility to Local Moves“. De Fina A. and Georgakopoulou, A. (eds.) The Handbook of Narrative Analysis. John Wiley \& Sons, Inc, 2015. 57-75.

Kostić-Tomović, J. „Obrasci tekstualizacije - jezička i kulturna uslovljenost na primeru porodičnih oglasa“. Kostić-Tomović, J. et al. (ur.). $U$ carstvu reči - jezici i kulture, Zbornik u čast prof. dr Jovanu Đukanoviću povodom 85. Rođendana. Beograd: Filološki fakultet, 2016. 122-153.

Labov, W., and J. Waletzky. „Narrative Analysis: Oral versions of personal experience“. J. Helm (ed.). Essays on the Verbal and Visual Arts. Seattle: University of Washington Press, 1967. 12-44.

Norrick, Neal R. Conversational Narrative: Storytelling in Everyday Talk. Amsterdam: John Benjamins B.V, 2000.

Polovina, V. Semantika i tekstlingvistika. Beograd: Čigoja štampa, 1999. 


\title{
Vesna Polovina
}

\author{
LINGUISTIC NARRATIVE AND ARGUMENTATIVE \\ FEATURES IN “JAZAVAC PRED SUDOM” BY PETAR KOČIĆ
}

\section{Resume}

The linguistic features of narrative and argumentative types of texts often appear in combination, and an interesting mixture can be found in "Jazavac pred sudom" by Petar Kočić. Our analysis of this text shows a specific arrangement of these two textual types and a number of specific linguistic expressions being used in developing the argumentation and narration. 